\title{
Oana Ludmila POPESCU* \\ German Quality in the Service of a European Public Sphere? An Analysis of the Deutsche Welle's European Journal program
}

\begin{abstract}
The economic crisis of the European Union has rendered the European public sphere as a forever emerging concept marked by uncertainties regarding its structure. In this context, eyes of both European officials and citizens turn towards the media, the main communication link between the EU and its citizens. The present paper looks at a media product that is designed to permeate multiple national public spheres, the weekly news show European Journal, a half-hour TV program produced by Deutsche Welle and rebroadcast by partner TV channels throughout Europe. Considering the main characteristics of the European public sphere as identified in the literature, with a focus on horizontal Europeanization, and using the method of content analysis, this paper looks at the means employed by the European Journal to support the integration process and to add a European dimension to national public sphere. Findings suggest that the type of public sphere promoted by the European Journal is not centered around the EU as a distinct entity, but around the member states, approach which supports the idea of a horizontal Europeanization.
\end{abstract}

Keywords: European public sphere, horizontal Europeanization, European Journal, Deutsche Welle.

\section{Introduction}

Times of crises are times of great revelations when all the weaknesses of a system or of a mechanism are brought to light in a complex, never before performed radiography. Only when it stops working, is the intricate mechanism of a clock exposed to the naked eye and all its unique, minuscule pieces become all of a sudden relevant and essential for the functioning of the whole. Likewise, the crisis of the European Union exposed the weaknesses of its institutional system, the malfunctions of its decision-making process and, last but not least, the enormous gap between the EU and its citizens.

While theoreticians like Jürgen Habermas (2012) consider that the balance of power in the organizational structure of the EU is shifting in favour of the European citizens, who are expected to act in a double quality, both as citizens of the Union and of a specific member state, ordinary people seem to be unaware of the impact the policies adopted in Brussels have on their everyday life. After a short review of Habermas' perception on the role of the European citizens and the necessity of increased popular participation in the European project, the paper will present some general considerations regarding the role and characteristics of the European public sphere as seen by the most reputed scholars in the field. Since the Europeanization of national public spheres comes across as the only viable solution for the emergence of the Eu-

* National University of Political Studies and Public Administration, Romania, oanaludmila@yahoo.com. 
ropean public sphere, we will then focus on the three forms of Europeanisation of public communication identified by Koopmans and Erbe (2003): the emergence of a supranational European public sphere, vertical Europeanisation and horizontal Europeanisation.

Against this theoretical background, the present paper looks at an interesting media product that is designed to permeate multiple national public spheres and has the potential to set a new trend in the European media landscape. The weekly news show European Journal, a half-hour TV program produced by Deutsche Welle, the German international broadcaster, transcends national boundaries and reaches a global audience by being rebroadcast by partner TV channels throughout Europe. According to the profile presented on its website, the $\mathrm{Eu}$ ropean Journal "delivers the inside take - reports on important political, economic and cultural developments in the EU with a strong focus on the European integration process". The aim of this article is to determine the means employed by the "magazine from Brussels" to support the integration process and to add a European dimension to national public spheres. By using the method of content analysis, we will tackle questions regarding the European dimension of the topics illustrated, the perspective they are presented from and the visibility of the European construction. Findings suggest that the type of public sphere promoted by the European Journal is not centered around the EU as a distinct entity, but around the member states, approach which supports the idea of a horizontal Europeanization.

In the dynamics of the new information age, the exchange of media products between public or private broadcasters from various member states of the European Union might become a generalized trend. Provided that the programs in question are samples of high-quality journalism focused on European topics, this could prove to be a viable solution to the limited coverage of European issues in national media and could raise awareness of the fact that, in a community of states, the political, economic and social realities of one member state affect the entire Union.

\section{An opportunity in disguise}

To a higher or lesser extent, the crisis affected all member states of the EU bringing upon them economic and social hardships, austerity measures and unrest at all levels of society. Yet Habermas (2012) manages to identify a secondary consequence of the crisis, one that could translate into an opportunity for the EU elites to overcome the democratic deficit. According to the German sociologist and philosopher "the economically generated apprehensions are inspiring a more acute popular awareness of the problems besetting Europe and are lending them greater existential significance than ever before" (Habermas, 2012, p. X). This means that the present circumstances, bleak as they may be, have caused a fracture in the "vicious circle of (non) communication" (Brüggemann, 2005, p.12) marked by a lack of intrest on the part of the public, the media and the political class to read, write and talk about European issues.

However, all the attention that the European project is currently enjoying could prove to be short-lived and devoid of any significant consequences on the long-term if politicinas do not „lay the European cards on the table without further delay” and „take the initiative in explaining to the public the relation between the short-term costs and the true benefits, and hence the historical importance of the European project" (Habermas, 2012, p. 6). Politics behind closed doors is no longer an option because the weaknesses of the European Union have 
already been exposed and citizens, especially from the countries most affected by the crisis, have started to publicly question the efficiency of the supranational mechanism. According to the Eurobarometer survey, trust in the EU remains at a low level, for the third succesive time, with only $31 \%$ of the citizens willing to put their trust in the European project (EB 81). However, it appears that more and more Europans are now convinced that their voice counts in the EU. The proportion of EU citizens who consider that their opinion is taken into account by EU politicians has reached $42 \%$, an increase of 13 percentage points since autumn 2013 (EB 81). Even if the results were definitely influenced by the European elections held in May, the citizens' trust in their power to influence the decision-making process is welcomed considering that, as Habermas (2012) puts it, the balance of power in the organizational structure of the EU has shifted in favour of the European citizens: ,at the European level, the citizens should be able to form judgements and make political decisions simultaneously and on an equal footing both as EU citizens and as members of a particular nation belonging to the EU" (p. 37). Increased popular participation is seen by Habermas as a necessary step to overcome the impasse reached by ,the process of European unification, which was constructed above the heads of the population from the very beginning" (p. 132).

If they are expected to act in a double quality, both as citizens of the Union and of a specific member state, people should also have access to information that allows them to cast intelligent votes and to understand the impact the policies designed in Brussels have on their daily lives. Here is where the role of high quality media and of the European public sphere becomes relevant. In order for people to have an accurate images of what is going on at European level, national public spheres must "gradually open themselves up to each other" and the media must not only "thematize and address European issues as such, but they must at the same time report on the political positions and controversies which the same topics evoke in other member states" (Habermas, 2012, p. 48). In other words, without a transnational discursive exchange between national public spheres, the formation of a genuine European space for debate is unlikely as the Europeanized public spheres remain segmented (Peters et al., 2005).

\section{The European Public Sphere - a forever emerging concept}

The fact that the citizens received back seats at the show staged by the European institutions in an "external locus of decision-making" (Schlesinger \& Foret, 2007, p. 416), determined the quick association of the so-called "democratic deficit" with a "communication deficit": "the discrepancy between Europe's institutional development, on the one hand, and the continuing predominance of the national political space as the arena for public debates and participatory citizenship, on the other, is at the core of Europe's democratic deficit" (Koopmans, 2007, p. 183). If, in the beginning, EU officials could afford to turn a blind eye to the communication issue, the rejection of the draf Constituton in the summer of 2005 by people in France and the Netherlands - two of the EU's founding states - and, later on, the initial rejection of the Lisbon Treaty by Ireland, demonstrated that the deficiences of the European project could no longer be ignored.

According to the report of the High Level Group on Media Freedom and Pluralism (HLG, 2013), "the democratic legitimacy of the European Union is closely dependent, however, on the emergence of a public sphere which is informed about European issues and able to engage in debates about them" (p. 39). The need to construct and consolidate a European pub- 
lic sphere has triggered the interest of many theoreticians, which has resulted in a great amount of literature on the topic. However, no consensus was reached with respect to the ideal structure of the forever-emerging European public sphere.

Whether it is viewed as "the engine of democratization" or as „the social and communicative infrastructure of democracy" (Trenz, 2005, p.1), the public sphere ia a fundamental brick in the foundation of any democracy since it creates the premisses for basic requirements of democratic societies: popular control of the political agenda (Dahl, 1971), public participation (Beetham et al., 2002; Held, 2006), representation, transparency and accountability (Beetham, 1994). In this public arena where debate is facilitated by the media, which act as purveyors of information, people can share opinions and ideas, can comment on the activity of their political representatives and question their decisions and they can suggest a certain course of action. Thus, this ,shared community of communication” (Risse, 2002, p. 10), this open field where a communicative exchange takes place (Trenz, 2008) also provides acces to information, another basic characteristic of democracy.

Whereas it is clear that the public sphere is ultimately a space where citizens discuss issues of public interest (Van de Steeg, 2004), the concept of European public sphere is still subject to hot debate: „the very idea of promoting a European public sphere, the possible emergence of European media, increased European awareness within the national public spheres, or increased national coverage of European affairs, is still controversial in many quarters" (HLG, 2013, p. 39). Theoreticians consider that the European public sphere is ,the prerequisite for better governance, legitimacy and citizens' participation in the emerging European polity” (Trenz, 2005, p. 5) and that it ,seeks to understand the engagement or lack of it among European citizens with the political project" (Golding, 2006, p. 3). Irrespective of the wording, the importance of this concept in humanizing and legitimising the EU, in bringing it closer to its citizens is easily perceived.

Many scholars argue that the only viable solution for the emergence of the European public sphere is the Europeanization of the national public spheres (Brüggemann, 2005; Kopper \& Leppik, 2006; Schlesinger \& Fossum 2007). The coverage of European topics and the actions of EU officials in the national public spheres as well as their evaluations from a European perspective that goes beyond national interest were identified as the main characteristics of this process of Europeanization (Bârgăoanu, Negrea \& Dascălu, 2010). In the emergence of this type of European public sphere, the national media play a crucial role as "according to the citizens themselves, their knowledge of the EU is derived largely from the mass media (television and radio)" (Kunelius \& Sparks 2001, p. 9). So, acting as facilitators of the public debates in society, the national media bear the responsibility for adequate coverage of European issues and politics and have to "use similar criteria of relevance and similar forms of reference across national publics spheres when discussing European issues" (Risse 2003, p.3). However, in order to speak of an authentic Europeanization of national public spheres, the European dimension of the issues debated must be "made visible in one way or another to the public" (Koopmans \& Erbe, 2003, p. 5). If the audience is not aware of the European-level origin of the topic debated at national level, if its transnational relevance is not highlighted in the media coverage, it is perceived as a domestic issue and the European dimension is lost.

Analysing the process of Europeanization of public communication, Koopmans and Erbe (2003) emphasised three different approaches: the emergence of a supranational European public sphere, vertical Europeanisation and horizontal Europeanisation (p. 6). The supranational European public sphere implies an interaction between European-level institutions and 
collective actors ideally facilitated by European-wide media. Vertical Europeanisation refers to „communicative linkages between the national and the European level” (p. 6) and has two dimensions: „bottom-up” - when national actors address European ones or European issues and „top-down” - when European actors express a point of view in national policies and public debates in line with European regulations and common interests. Horizontal Europeanisation refers to „communicative linkages between different member states” (p. 6) and it also has two versions: "In the weak variant, the media in one country cover debates and contestation in another member state, but there is no linkage between the countries in the structure of the claim-making itself. In the stronger variant, actors from one country explicitly address, or refer to actors or policies in another member state" (Koopmans \& Erbe, 2003, p. 6-7).

In analysing the means employed by the weekly news show European Journal to support the integration process and to add a European dimension to national public spheres, this paper will focus on instances of weak horizontal Europeanisation, which is supposed to strengthen the connection between member states, without ignoring traces of vertical Europeanization, be it bottom-up, when regular citizens presented in the reports make references to European rights or regulations, or top-down, when EU officials make comments on the situation in a certain member state.

\section{European Journal - the Magazine from Brussels}

As we have seen in the previous section, the role of mass media in the creation and consolidation of the European public sphere is undisputable. Irrespective of the type of public sphere taken into consideration, the communication flow between the EU and its citizens is facilitated by the media, which provide an arena for public debate, disseminate information and increase the level of participation in the public debate on European issues. The High Level Group on Media Freedom and Pluralism (2013) reinforces the link between mass media and the citizens' level of participation and engagement in society which is ,shaped by the ability of the media to awaken and maintain their interest in a variety of issues. If reports produced by the media are superficial, unprofessional, visibly biased or just plain boring, citizens will "turn off" and disengage from topics that may have important consequences for them" (p. 30).

However, if we are to consider past experiences, attempts to establish pan-European media have not met with success. Established in 1986 by four public service broadcasters from Germany, the Netherlands, Ireland and Italy, the Europe TV channel proved to be short-lived (Kleinsteuber, 2001). The newspaper The European shared a similar fate while, according to Koopmans and Erbe (2003), other EU media products ,lead a marginal (and often heavily EUsubsidized) existence (e.g., the television station Euronews or the independent, but limited in terms of expert readership, European Voice)" (p. 3-4). The scholars argue that transnational media that have managed to create a name for themselves in the media landscape (e.g. $C N N$, BBC World, International Herald Tribune, Financial Times) „have a global, rather than European profile and audience" (p. 4).

The solution to the problems encountred by European-wide media could lie in the exchange of media products between public or private broadcasters from various member states of the European Union. Deutsche Welle, Germany's international broadcaster, favors this approach. It is regulated by public law and financed by federal tax revenue, but, according to its mission statement, ,it carries out its legally defined mission while remaining journalisti- 
cally independent". Deutsche Well produces multilingual media services for a global audience and the principles, vision and values expressed in its mission statement emphasize its European dimension: „We communicate German points of view and European perspectives. We promote intercultural dialogue and work to further international understanding and tolerance. [...] We have a cultural mission and present the culture from Germany and Europe".

European Journal, the focus of this paper, is a weekly TV program produced by the Deutsche Welle studios in Brussels. According to the profile presented on its site, the 30 minute „magazine from Brussels”: ,delivers the inside take - reports on important political, economic and cultural developments in the EU with a strong focus on the European integration process. The European Journal features issues that move Europeans and shows Europeans on the move". A regular edition is made up of four or five stories (usually four), which are short documentaries with variable length, from at least 4 minutes to around 7 minutes, that cover topics in depth, the format being less rigid than the one used in standard news journals. Since it presents a limited number of subjects per edition, the stories focusing on people, places or events from a particular country, usually European, are placed in wider contexts and background information is supplied. From time to time, special editions are dedicated to portraying countries or covering spectacular events. The program is in English but, together with the right to rebroadcast it, partner TV channels from different countries also receive the script of each edition, thus being able to subtitle or dub the program and solving the linguistic dilemma that hindered the development of common European media.

Since it is designed to permeate multiple national public spheres and has the potential to set a new trend in the European media landscape, this paper looks at the means employed by the "magazine from Brussels" to support the integration process and to add a European dimension to national public spheres. Provided that the programs that make the object of transnational exchange in the dynamics of the new information age are samples of high-quality journalism focused on European topics, this practice could increase the coverage of European issues in national media and could raise awareness of the fact that, in a community of states, the political, economic and social realities of one member state affect the entire Union.

\section{Methodology}

In order to determine the approach of the "magazine from Brussels" towards the European integration process and the Europeanization of national public spheres, this paper analyses the 28 editions of the European Journal broadcast in the time span of six months, from November 20, 2013 to May 28, 2014 (one edition per week). The method employed was content analysis and the unit of analysis was the story. The corpus comprised a total of 119 storyes, the equivalent of roughly 14 hours.

The research questions focused on three aspects: the European dimension of the topics presented in the stories, the perspective they are presented from and the visibility of the European construction.

RQ1. What types of topics are presented in the stories?

Considering that the European Journal is supposed to „deliver the inside take - reports on important political, economic and cultural developments in the EU with a strong focus on the European integration process", the promotion of European topics is a prerequisite for the ac- 
complishment of this task and it should dominate in terms of coverage national or local issues without EU relevange, even if the latter would probably score higher in the preferences of the public. Moroever, if this media product is to support the Europeanization proccess of various national public spheres, the European dimension should be one of the basic criteria in the selection of topics. Content analysis will show whether the TV program adopts a straighforard approach towards Europeanization, by tackling genuine European subjects, or a mitigated one, more „viewer-friendly” in terms of impact, by presenting national issues with EU relevance.

RQ2. From what perspective are the topics presented?

Another requirement for the Europeanization of national publis spheres by means of the mass media is the evaluation of the topics from a European perspective that goes beyond national interest. Lack of awareness on the part of the public of the European-level origin of the topic debated at national level leads to its perception as a domestic issue and, consequently, to the loss of the European dimension. The analysis will show if the EU is generally presented as a main actor in the stories or if it is usually viewed from the persective of another state, be it member state, candidate country or third country.

Other aspects highlighted in the context of the perspective the topics are presented from should point to instances of vertical Europeanisation. The sources interviewed or cited in the stories support „bottom-up” Europeanization, when regular citizens make references to European rights or regulations, or "top-down" Europeanization when EU officials make comments on the situation in a certain member state. It remains to be seen how active EU officials are in terms of expressing their point of view and how willing to engage in a dialogue, be it mediated by television, with the citizens.

RQ3. How visible is the European construction in the European Journal?

According to the profile presented on its site the „European Journal features issues that move Europeans and shows Europeans on the move". Considering that these stories that „move Europeans" reach audiences from different member states, the program appears to be a potentially efficient instrument of horizontal Europeanisation but, in order for it to encourage the consolidation of a supranational European public sphere and be considered a true sample of European-wide media, the European Union, as a distinct entity, should enjoy a certain amount of visibilty in the stories presented. Content analysis will indicate the priority of European issues, their visibility and the frequency with which the EU is invoked.

\section{Findings}

According to its designated purpose, ,the Magazine from Brussels” delivers an inside take on Europe. However, the fact that out of a total of 119 stories only two concern a truly European topic is a clear indication that we should not equate Europe with the European Union. The first European topic identified was presented in a special edition of the European Journal broadcast on Ianuary 1, 2014 and dedicated to the 10th anniversary of the eastern EU enlargement. In this short history lesson, the accession of the 10 new countries was graphically compared to conquering the summit of Mount Europe. The other four stories of the edition, however, focused on national issues with EU relevence so, in spite of the cause for celebraton, the European construction as such was not in the centre of attention for long. While it is 
important to remember the moments that marked the history of the EU, it is unlikely that this kind of subjects will trigger transnational debates.

Quite the opposite could be said about the second EU topic identified. Dealing with the hot subject of the European elections, the first story of the edition broadcast on May, 21st had all the necessary ingredients to fuel public debates. Following the campaign trail in France, the story pesented the electoral platforms of the two front-runners for the presidency of the European Commission: Martin Schulz and Jean-Claude Juncker. Although there was no special edition dedicated exclusively to the European elections, in May, the European Journal was clearly dominated by national issues that revolved around the elections.

If we are to consider this second category of topics - national issues with EU relevance the European Union gains a few points in terms of visibility. 44 out of the 119 stories tackle this type of topic (accounting for 37\% of the total number of stories), while national issues without EU relevance come second in terms of visibility, being the subject of 38 stories (32\%). However, the 5\% difference cannot lead to the conclusion that national issues with EU relevance occupy a special position on the agenda. Although national topics, irrespective of their nature, are by far the most popular (69\%), local or regional issues are not neglected and account for almost $23 \%$ of the stories. Surprisingly, even global and international issues $(6.7 \%)$ are more visible than EU topics.

Analysing the stories from the perspective of their general domain (political, economic, social, cultural, environmental, healthcare, soft news), we find that $50 \%$ of the national issues with EU relevance pertain to the political sphere. $27 \%$ of these issues are subscribed to the social domain while $9 \%$ of them belong to the cultural sphere. Economic and environmental issues account for only 7\% and 5\% respectivelly of the stories with EU relevance. The first three positions of the hierarchy are maintained if we refer to the total number of stories analysed, but the percentages vary significantly (Fig.1).

Figure 1. Domain of the stories.

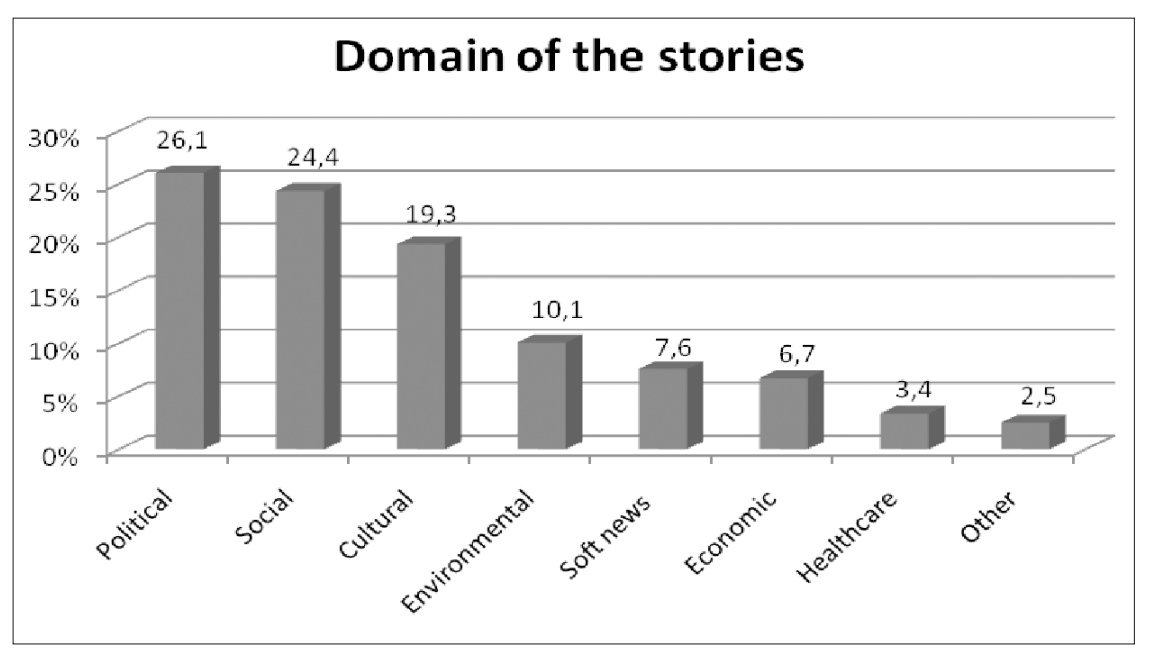

Political issues still dominate the scene (26.1\%) but they are followed closely by social matters (24.4\%) and cultural subjects (19.3\%). Environmental problems are the subject of 5 out of the 8 stories dealing with global/international issues and their consequences at Euro- 
pean level are highlighted in only 2 stories. Economic issues are rarely presented in the European Journal (6.7\%) and only ocasionally framed in a European context.

The European Union occupies the same marginal position if we look at the main type of actors featured in the stories (Fig. 2). It is in the limelight only in the above-mentioned stories, one celebrating the eastern enlargement which took place exactly 10 years ago and the other one presenting the two front-runners for the presidency of the European Commission. Although it is not awarded the centre position, the EU is present as a secondary actor in 15 other stories, mainly in relation to member states. Its popularity as a secondary actor increses significntly in May, when it is referred to in 6 stories tackling the subject of European elections, apart from the one in which it is featured as a main actor. In spite of the fact that the topic of these stories - the candidates for a seat in the European Parliament - has both national and European relevance, the EU only appears to serve as pretext for debates that are limited to domestic issues and do not transcend national boundaries. Thus, being mentioned as a secondary actor, the European project becomes visible in as far as it plays a relevant role from various national perspectives.

Figure 2. Main actors.

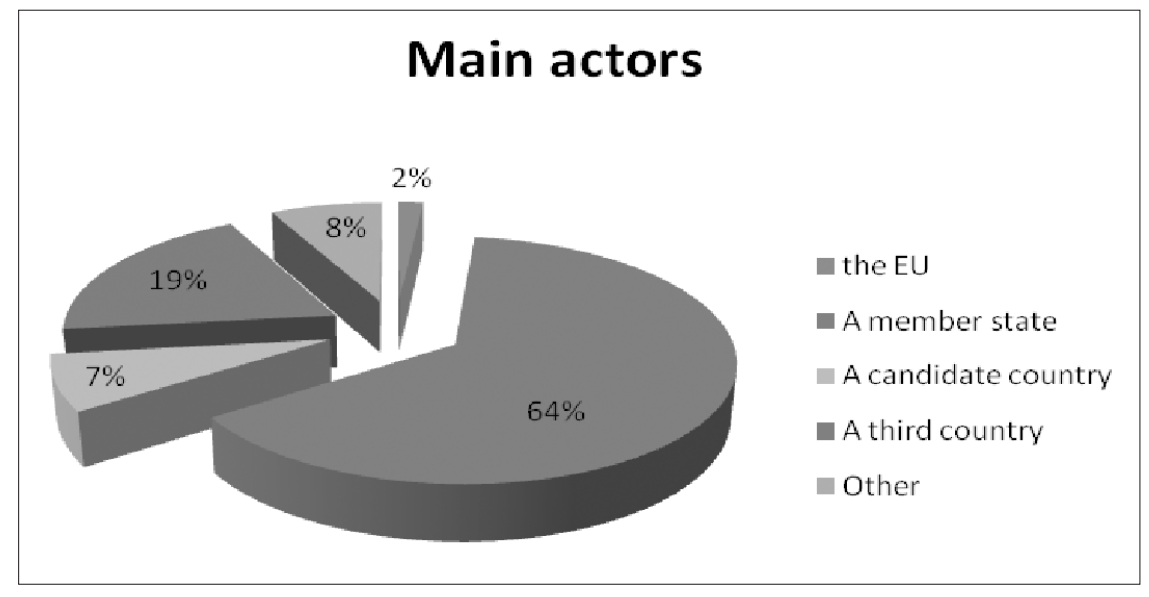

At the top of the hierarchy of the main actors we find France, which is featured in 12 stories, followed by Spain which constitutes the context for 9 stories. On the third position we find Ukraine which appears in 8 stories, while the forth position is devided between Belgium and Italy, with 7 stories each. It does not come as a surprise that Ukraine, a third country, is featured more often than other old member states considering the delicate political situation in this country and its consequences on the relation between EU and Russia. The latter is the subject of five stories and it also assumes a secondary role in a number of storis concerning Ukraine. Although the scene is clearly dominated by member states, they do not compensate the absence of the European Union as an individual actor, with distinct mechanisms, characteristics and policies.

Apart from the main and secondary actors presented in the stories, the national or European perspective on the issues illustrated is also influenced by the sources of information used. Up to four types of sources were identified per story, but here too, voices representing the European perspective are rarely heard (Fig. 3). 
Figure 3. Sources interviewed.

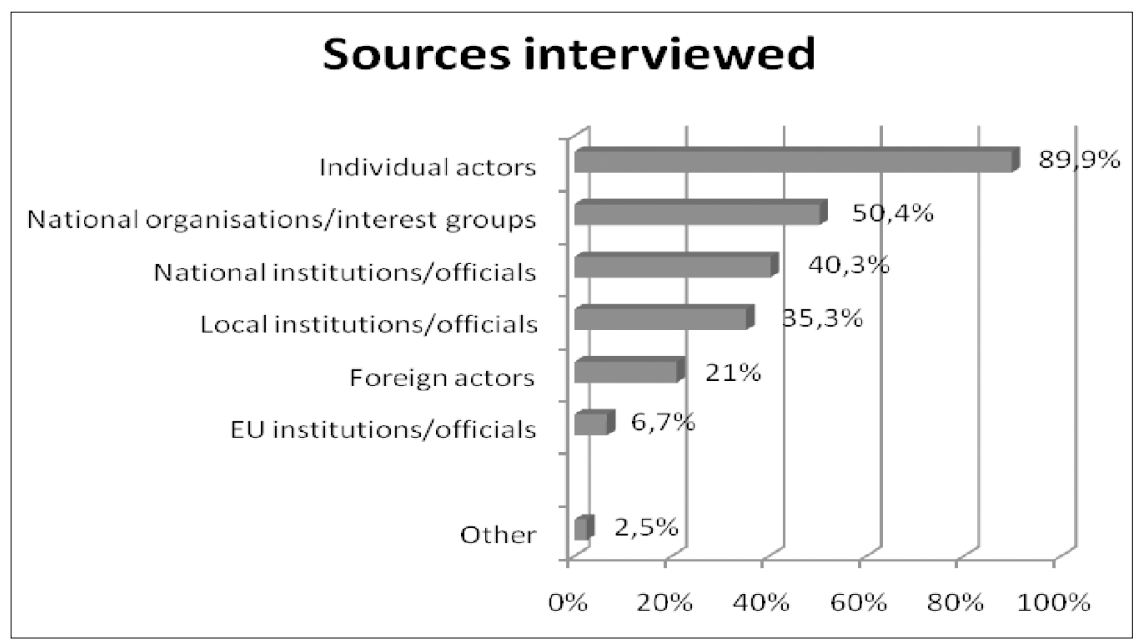

Only in eight stories out of a total of 119 is the official position of EU institutions or officals specified. This accounts for only $7 \%$ of the stories and shows that the debate of the issues in question does not transcend the national public spheres. It also indicates the reduced level of involvement of EU officials in matters concerning the general public. The hierachy of sources is dominated by individual actors who are interviewed or cited in the majority of the stories (90\%), which illustrates the fact that the opinion of regular citizens is highly valued and that public opinion is not to be neglected irrespective of the nature of the topic discussed. Supporting the citizens' direct interest, national organisations or interest groups represent the second most cited source, being mentioned in $50 \%$ of the stories while national institutions or officials are ranked third in the hierarchy of sources with a visibility of only $40 \%$.

Assessing the length of the stories in relation to the topic presented, the analysis revealed that, with a duration of only 270 seconds, the first story featuring a truly European subject is more than one minute shorter than the average lenght of the rest of the stories (346 seconds), thus having a reduced visibility, while the second story, with a duration of 405 seconds, is almost a minute longer. National issues with EU relevance do not variate significantly from the 348 seconds mean, but national issues without EU relevance tend to be slightly longer, totalizing on average 360 seconds.

In order to determine the prominence of EU related topics, the placement of the stories in the jounal was assessed (Table 1). Major topics, the ones that are expected to attract a considerable audience are generally placed in the first position. While the two stories concerning a truly European topic are indeed presented first, other stories related to national issues with EU relevance usually dominate the second and fourth position. The first position is mainly occupied by national issues without EU relevance and even local/regional issues are expected to draw more attention than EU related topics, $22 \%$ of them being placed on the first position, with only $20 \%$ of the issues with European relevance enjoying the same primacy. This indicates that the viewers are more attracted by domestic issues that concern them directly and are not used to place the subjects in wider contexts, to look at their transnational consequences or implications. 
Table 1. Placement of stories in the journal.

\begin{tabular}{|c|c|c|c|c|c|c|}
\hline & \multicolumn{5}{|c|}{ Topic of the story } \\
\hline & & $\mathrm{EU}$ issue & $\begin{array}{l}\text { National issue } \\
\text { with EU } \\
\text { relevance }\end{array}$ & $\begin{array}{c}\text { National issue } \\
\text { without EU } \\
\text { relevance }\end{array}$ & $\begin{array}{l}\text { Local/regional } \\
\text { issue }\end{array}$ & $\begin{array}{c}\text { Global/interna } \\
\text { tional issues }\end{array}$ \\
\hline \multirow{5}{*}{$\begin{array}{l}\text { Placement } \\
\text { in the } \\
\text { journal }\end{array}$} & First & 2 & 9 & 11 & 6 & 0 \\
\hline & Second & 0 & 14 & 8 & 3 & 3 \\
\hline & Third & 0 & 9 & 9 & 6 & 4 \\
\hline & Fourth & 0 & 10 & 7 & 9 & 1 \\
\hline & Fifth & 0 & 2 & 3 & 3 & 0 \\
\hline \multicolumn{2}{|c|}{ Total number of stories } & 2 & 44 & 38 & 27 & 8 \\
\hline
\end{tabular}

Although EU's visibility as an actor and the presence of its officials as a source of information interviewed in the reports is extremely reduced, the European construction is referred to occasionally in $51 \%$ of the stories, usually in relation to topics with EU relevance. This does not translate into a substantial increase in visibility, but its existence is at least acknowledged and it is associated with certain values and principles that should be taken into consideration by member states and candidate contries.

The most frequent characteristics attributed to the EU regard the right of free movement (of persons, goods, services and capital) which is mentioned in 11 stories, its capacity to provide financial support, alluded to in 8 stories, and its focus on modernity and support for democracy mentioned in 6 reports each. Other values associated with the EU refer to the maintenance of peace, anti-discrimination and cultural diversity. However, only $58 \%$ of these European values and principles are mentioned explicitly, the other $42 \%$ being implied from the context. Considering the fact that $90 \%$ of the sources cited or interviewed in the European Journal are individual actors, it comes as no surprise that freedom of movement is the most appreciated European principle as it impacts the lives of citizens in a direct and substantial way.

Analysing the general attitude towards the issues illustrated, findings show a clear tendency towards stories marked by conflict, tensions and disagreement. $67 \%$ of the issues presented are portrayed as negative, depicting events, situations or actions that are detrimental to the common good, while only $33 \%$ of the stories illustrate issues that need to be encouraged and promoted. From this respect, the European Journal is in line with general media practices that are focused on negative subjects, such as disputes and conflicts, which appear to make good audiences. Although the two stories dealing with genuine European subjects are presented in a positive light, national issues with EU relevance represent $42 \%$ of the subjects with negative implications. This situation could be explained by the fact that $50 \%$ of these issues pertain to the political sphere, a domain that is usually marked by dispute and tension. It appears that national issues without EU relevance are presented in a somewhat brighter perspective, accounting for $36 \%$ of the negatively-framed issues. However, it must be specified that this kind of topics are dominated by social and cultural issues. The only category of topics dominated by positive events, situations or activities is the one depicting issues with local or regional relevance. This category is also rich in cultural topics and it includes individual or collective success stories that impact the life of a community. 


\section{Discussion}

Being promoted as „the Magazine from Brussels”, the weekly news show European Journal produced by Deutsche Welle is placed from the very beginning in the sphere of European media. As it has already been shown in the theoretical section of this paper, the main characteristics of this type of media refer in the first place to the coverage of European topics from a European perspective and to the ability of generating and reinforcing debate at European level. So, does the program European Journal qualify as a genuine sample of European media that supports the integration process and adds a European dimension to various national public spheres?

In as far as the European dimensions of the topics presented is concerned, findings show clearly that truly European subjects are almost absent from the agenda. Given the wide-spread assumption that audiences still perceive European matters as distant from their daily existance, more attention is given to domestic issues with national and local relevance that have a stronger impact on the citizens. A straighforward approach towards Europeanization is probably considered too risky, thus, genuine European subjects are usually avoided and the European dimension of certain topics only emerges in a mitigated, more ,viewer-friendly" form, in the guise of national issues with EU relevance. Successful as it may be, this tactic does little to reduce the distance between the UE and its citizens who are not informed about European issues, are not encouraged to engage in debates about them and are not stimulated to place the subjects in wider contexts, to look at their transnational consequences or implications.

The overwhelming majority of the stories presented concern domestic issues, either with $\mathrm{EU}$, national or regional relevance. However, judging from the sources cited or interviewed in the reports, even debates on national issues with EU relevance are presented within the borders of national public spheres. In the majority of the cases, the EU only appears to serve as a pretext for debates that are limited to domestic issues and do not transcend national boundaries. EU institutons or officials are hardly ever cited, indicating their reduced level of involvement in matters concerning the general public, while opinions of regular citizens and national organisations or interest groups are highly valued. The perspective on the subjects is also influenced by the main actors in the stories. The fact that the scene is dominated by member states suggests the fact that the European integration process is supported not by promoting the European Union as a distinct entity, but by presenting its members as individual nations occasionaly sharing similar interests and obligations. Moreover, considering that, from the geographical perspective, the EU member states dominate the continent, their presence in a large number of reports is not only justified, but also inevitable.

With respect to the priority of national issues with EU relevance, findings suggest that these are not expected to decisively attract the attention of the public and are predominantly placed on the second or fourth position in the hierarchy of stories presented per edition. However, the two genuinely European subjects, one deling with an important moment in the history of the EU and the other one focusing on the electoral platforms of the two front-runners for the presidency of the European Commission, do enjoy primacy and are expected to have a strong impact on the audiences from all the member states in which the European Journal is broadcast. Apart from these specific situations, the first position is generally occupied by national issues without EU relevance, but issues with local or regional influence are not neglected either. This indicates that, although European matters ultimately affect them all, people are usually more interested in their immediate reality and subjects are more likely to stir 
a debate or to stimulate reactions if they are framed within a familiar context. A similar logic explains the fact that, from all the values and principles that the European Unon stands for, freedom of movement is the most appreciated by citizens who experience it directly. In terms of media practices, the European Journal is in line with general tendencies as it focuses on stories that depict disputes and conflics which appear to make good audiences.

If we take into consideration all the distinguishing features of ,the Magazine from Brussels", pinning down the exact model of a European public sphere that it endorses proves to be a difficult task. The program is in English, the unofficial lingua franca of the EU, but, since partner TV channels from different countries receive the script of each edition and are offered the possibility to subtitle or dub the program, the language barrier is eliminated and all EU citizens have, at least theoretically, the opportunity to recive the program in their own language. Thus, one of the major impediments in the creation of a common European-wide public sphere is overcome. Morover, the fact that it can be rebroadcast by national TV channels may provide „the Magazine from Brussels” with a more opened and relaxed audience that is not watching a foreign channel, but receives a product wrapped in a familiar package.

While it is true that European Journal does meet some of the characteristics of Europeanwide media, the present analysis shows that the basic requirement for the emergence of a supranational European public sphere, that of an interaction between European-level institutions and collective actors, is not satisfied. However, with respect to the process of Europeanization of various national public spheres, Deutsche Welle's program does make a contribution, but not in the classical way. According to the findings presented in this paper, „the magazine from Brussels" does not cover European topics from a European perspective and the public sphere promoted is not centered around the EU as a distinct entity, but around the member states, approach which supports the idea of a weak horizontal Europeanization. Instances of "bottom-up" vertical Europeanization are also identified whenever regular citizens featured in the stories make references to European rights or regulations, but "topdown" vertical Europeanization is largely absent since EU officials are not keen on expressing their point of view and on engaging in a mediated dialogue with the citizens.

\section{Conclusion}

Highly debated by theoreticians, much desired by European officials and partially ignored by European citizens, the European public sphere seems to pertain to an ideal reality. However, the lack of it has dire consequences upon a community torn by crises and nationalistic egos and translates into a communication deficit between Europe and its citizens. The emergence and consolidation of a genuine European public sphere is not likely to solve all the problems of the European construction but it could humanise and legitimise the EU, bringing it closer to the people whose lives it is supposed to improve. Scholars have yet to identify a recipe for its emergence and consolidation, but it is certain that it depends on the formation of a collective European identity and, last but not least, on the media. Capitalizing on the the attention that the European project is currently enjoying due to its unprecedented crisis, the media could stimulate popular participation in the decision-making process by promoting transnational debates.

In the dynamics of the new information age, the exchange of media products between public or private broadcasters from various member states of the European Union could prove 
to be a viable solution to the limited coverage of European issues in national media. Although the TV program European Journal, produced by Deutsche Welle, Germany's international broadcaster, does not promote a public sphere centered around the EU as a distinct entity, but around the member states, it supports the Europeanization of various national public spheres, and thus the integration process, by promoting the idea of a weak horizontal Europeanization. European Journal does not contribute to the emergence of a supranational European public sphere, nor does it not venture into promoting genuine European subjects, but, by presenting stories that concern political, social, economic and cultural realities of various European countries, the program improves the connection between them and raises awareness of the fact that, in a community of states, the problems and challenges faced by one member state affect the entire Union.

After all, European Journal is in line with the general principles of Deutsche Welle. Marking the $60^{\text {th }}$ anniversary of this media organization, in an interview broadcast on April 28, 2013, Deutsche Welle's Ex- Director General, Erik Bettermann, who was in office for more than 12 years and retired in September 2013, declared: "We seek to reach a global audience. [...] We're concentrating now on building social and cultural bridges, promoting understanding between peoples. You can't underestimate the value of programs like this. They've showed enormous effectiveness".

\section{References}

Bârgăoanu, A., Negrea, E., \& \& Dascalu, R. (2010). The Emergence of a European Public Sphere: An Analysis of Europe's News Website www.presseurop.eu. Journal of Media Research, issue 6, 3-17.

Beetham, D. (1994). Defining and Measuring Democracy, London: Sage/ECPR.

Beetham, D., Bracking, S., Kearton, I., \& Weir, S. (2002). International IDEA Handbook on Democracy Assessment. The Hague: Kluwer Law International.

Brüggemann, M. (2005). How the European Union Constructs the European Public Sphere: Seven Strategies of Information Policy, TranState Working Papers, No. 19, 1-25.

Dahl, R. (1971). Polyarchy: Participation and Opposition. New Haven CT: Yale University Press.

Fossum, J. E., \& Schlesinger, P. (2007). The European Union and The Public Sphere: A Communicative Space in the Making? In Fossum, J. E. \& Schlesinger, P. (Eds.). The European Union and The Public Sphere: A Communicative Space in the Making? New York: Routledge, 1-20.

Golding, P. (2006). Theoretical Issues Arising form the Research Project. In D6: Theory Building. European Identity Building/European Public Sphere, AIM Project, Erich-Brost-Institute Centre of Advanced Study in International Journalism, 12-21.

Habermas, J. (2012). The Crisis of the European Union. A Response. Malden: Polity Press.

Held, D. (2006). Democracy, the Nation-State and the Global System. In Models of Democracy. Third Edition. Cambridge: Polity Press.

Kleinsteuber, H. J. (2001). Habermas and the Public Sphere: from a German to a European Perspective. The Public, Vol. 8, 95-108.

Koopmans, R. (2007). Who Inhabits the European Public Sphere? Winners and Losers, Supporters and Opponents in Europeanized Political Debates. European Journal of Political Research, 46, 183-210.

Koopmans, R., \& Erbe, J. (2003) : Towards a european public sphere? Vertical and horizontal dimensions of europeanised political communication. Veröffentlichungsreihe der Arbeitsgruppe Politische Öffentlichkeit und Mobilisierung des Wissenschaftszentrums Berlin für Sozialforschung, No. SP IV 2003-403

Kopper, G. G., \& Leppik, T. (2006). Introduction. In D6: Theory Building. European Identity Building/European Public Sphere, AIM Project, Erich- Brost-Institute Centre of Advanced Study in International Journalism, 2-9. 
Kunelius, R., \& Sparks, C. (2001). Problems with a European Public Sphere. The Public, Vol. 8, 5-20.

Peters, B., Sifft, S., Brüggemann, M., Kleinen-v. Königslöw, K., \& Wimmel, A. (2005). National and Transnational Public Spheres. Beyond the Nation State? Special Issue of European Review 13 (1):139-160. Cambridge: Cambridge University Press.

Risse, T. (2002): How Do We Know a European Public Sphere When We See One? Theoretical Clarifications and Empirical Indicators. The IDNET Workshop "Europeanization and the Public Sphere", European University Institute, Florence, February 20-21,

Risse, T. (2003). An Emerging European Public Sphere? Theoretical Clarifications and Empirical Indicators. Paper presented to the Annual Meeting of the European Union Studies Association (EUSA), Nashville TN, March 27-30, 2003.

Schlesinger, P., \& Foret, F. (2007). Political Roof and Sacred Canopy? Religion and the EU Constitution. In J. K. Fossum, P. K. Schlesinger \& O. Geir (eds), ARENA Report No 2, 113-139.

Trenz, H.J. (2005). Review Essay: The European Public Sphere: Contradictory Findings in a Diverse Research Field. European Political Science, 00, 1-14.

Trenz, H.J. (2008). In Search of a European Public Sphere. Between Normative Overstretch and Empirical Disenchantment. RECON Online Working Paper No. 07, 1-16.

Van de Steeg, M. (2004). Does a Public Sphere Exist in the European Union? An Analysis of the Content of the Debate on the Haider-Case. EUI Working Paper SPS, No. 5, 1-21.

Vike-Freiberga, V., Däubler-Gmelin, H., Hammersley, B., \& Pessoa Maduro, L.M. (2013). A free and pluralistic media to sustain European democracy. The Report of the High Level Group on Media Freedom and Pluralism, p. 1-51. Retrieved July 24, 2014, from http://ec.europa.eu/information_society/media_taskf orce/doc/pluralism $/ \mathrm{hlg} / \mathrm{hlg}$ _final_report.pdf

*** Standard Eurobarometer 81

http://ec.europa.eu/public_opinion/archives/eb/eb81/eb81_first_en.pdf.

*** http://www.dw.de/european-journal-the-magazine-from-brussels/p-220045-9798.

*** http://www.dw.de/about-dw/mission-statement/s-8852. 